UDC 81'06:811.16.81'367.2

DOI https://doi.org/10.32841/2409-1154.2020.46-1.34

Zhaboruke O. A. (1949-2019),

Grand Doctor of Philology, Professor

Zhaboruke I. A., Candidate of Philology (Ph. D.), Associate Professor at the Germanic Philology and Methods of Foreign Languages Teaching Department South Ukrainian National Pedagogical University named after K. D. Ushynsky

\title{
THE PROBLEM OF IMPERSONAL SENTENCES IN MODERN SLAVIC LANGUAGES
}

Summary. The problem of relations between language and speech structures, and, in particular, between their main units - the logical and grammatical structures of predication belongs to the most essential problems of linguistics. This problem comes into existence due to a number of language phenomena, whose characteristic feature is that they cannot be projected onto a logical proposition. It distinguishes them from a great majority of utterances of Indo-European languages.

In Slavic languages these phenomena cover three types of cases. These are, first of all, the so called "one-member impersonal sentences", "one-member nominal sentences" and such utterances, typical of these languages, as («Борщу ціла миска», «Воды - по колено», “Mrówek naleciało”), and the like. There are many contradictory views regarding the character of their relations with forms of thinking.

As we see it, it can be explained by the fact that, under certain conditions predicativeness overlaps the formed structure of predication - the bearer of the thought, and lends the thought a bit new accentuation, thus widening the capacity of language. As a result, on the level of language, we have a sentence, and on the level of speech - an utterance whose purpose (function) is to complete the idea, to lend certain connotation to its meaning.

The cases analysed in the article serve a good example of how thinking uses verbal "ore" for several times to adapt it to its own needs. Besides, they serve as evidence of dialectical unity between two main forms of reflection - predicativeness and predication, which may manifest itself in the diffusion of the two forms, transfer of one form into the other.

All abovementioned cases have the same origin - all of them are nothing more but the language "imprint", the "result" of the "efforts" of thinking in its everlasting aspiration tendency to overcome the irresistible obstacle which exists between the means of the language and the infinity and diversity of the objective world around us.

Key words: Impersonal sentence, one-member sentence, nominal sentence, utterance-non-sentence, one-member nominative propositions, predicate, predication, predicativeness.

Stating the problem. The problem of relations between language and speech structures, and, in particular, between their main units - the logical and grammatical structures of predication belongs to the most essential problems of linguistics. This problem comes into existence due to a number of language phenomena, whose characteristic feature is that they cannot be projected onto a logical proposition. It distinguishes them from a great majority of utterances of Indo-European languages.
In Slavic languages these phenomena cover three types of cases. These are, first of all, the so called "one-member impersonal sentences” («Світає», «Морозить», «Уже вечоріло»), “one- member nominal sentences” («Зима», «Ніч», «Мороз») and such utterances, typical of these languages, as («Борщу - ціла миска», «Воды - по колено», "Mrówek naleciało", «Старику под семьдесят», «Мне душно», and the like.)

Analysis of the existing viewpoints. The nature of these phenomena has not been clarified yet. Thus, the grammatical status of utterances like «Морозить», «Світає», and so on, remains the bone of contention among linguists. Some linguists consider them to be a reflection of a one-member subjectless proposition $[1$, p. $2 ; 14$, p. $16 ; 3$, p. $30 ; 4$, p. 20, p. 220], others project them directly onto the objective reality and regard them as "states and processes irrespective of the doer" [5, p. 71-72; 6, p. 82, p. 129]. The advocates of the two-member proposition, on the contrary, firmly believe in the "personal" character of the utterances under consideration. Здесь дует > Дует сильньй ветер. Льет, как из ведра > Дождь льет, как из ведра.There is also another point of view, according to which such utterances are regarded "personal" purely on the language basis - the third person singular is meant [7, p. 117; 8, p. 138].

The syntactic interpretation of these utterances is also controversial. Some grammarians believe the verbal component of this kind of utterances to be the main member of a monosyllabic sentence. It correlates with neither subject, nor predicate [6, p. 37; 9, p. 13-14]. Other linguists state that it is the main member that correlates with the subject and the predicate, still being different from both of them $[4$, p. $76 ; 10$, p. 106]. Still others consider them to be a real predicate [7, p. 31; 11, p. 312-313]. As for the term "impersonal", used with regard to these utterances, it is also controversial: in some cases it denotes the absence of the subject of the proposition or the "doer" $[1$, p. 76; 7, p. 129], in other cases - the absence of a noun in Nominative case and an "impersonal" verb (which is sometimes called an "unreal" third person singular [2, p. 64], or such, that is used in an "improper" meaning [2, p. 26]).

There are many contradictory views regarding the so called monosyllabic nominative sentences and, first of all, regarding the character of their relations with forms of thinking. The most popular point of view in linguistics is of their immediate interrelation with the objective reality - with the folded process of the objective reality, with one situation [7, p. 125-126; 12, p. 71-72]. Often enough, the nominative utterances are projected onto one-mem- 
ber propositions $[13$, p. $23 ; 14$, p. 11-12; 9, p. 30]. Inconsistent is the treatment of nominative sentences in the dictionary of linguistic terms by D.I. Ganych and I.S. Oliynykh. Thus, in one case these sentences immediately correlate with the objective reality [12, p. 126], in some other - with a folded proposition [Ibid., p. 145]. What concerns syntactic status of such utterances, the situation around this problem in linguistics is clearly formulated by G.A. Zolotova: "The qualification of nominative sentences has always been problematic. Some linguists believe them to belong to a subject type, others - to a predicate type of sentences, still others think that in the only member of such sentences, the subject is connected with the predicate" [15, p. 22].

Utterances with a noun (a pronoun) in oblique case in the initial position also cause serious controversy. These are utterances of the type: «Воды - по колено», «Ребенку - год», «Борщу - ціла миска», etc. As we have already noted this type of utterances is rather widely spread in Slavic languages, which provides some linguists a basis for claiming it determining factor for the structure of these languages.

Let's begin analysing the polar points of view to these structures. According to one of them, such utterances (with the exception of a few types) express "processes and states without regard to the doer" and are grouped together with impersonal utterances like: «Світає», «Морозить», and so on [12, p. 76-77]. According to another one, these utterances reflect the structure of a two- member proposition and should be qualified as personal two-member sentences. The first component of such sentences - a noun (a pronoun) in an oblique case is considered the subject [6, p. 104, p. 130; 3, p. 56, p. 178]. A considerable number of grammarians recognize an utter inconsistency to the structure of the proposition, in particular, the monosyllabic character of the grammatical structure with a two-member nature of the proposition this kind of sentences correlate with. Such sentences can be qualified as "one-member subject" sentences [5, p. 11-12], or "one-member - monosyllabic" [7, p. 98-99] (the terms "one-member", "subject" denote the correlation with a two-member proposition), and finally, - as "predicative-subjectless" [16, p. 64, p. 125] (In the latter case the term "subjectless" denotes the absence of the subject in the grammatical structure of this type of sentences).

Analysis of theoretical sources, whose aim was to clarify these problems, indicated that in linguistics as well as in philosophy, namely in the theory of reflection, there are quite enough interesting ideas, which after certain reconsideration, develop into a clear picture of the process of reflection. Let us highlight the most essential details of this picture. Perhaps the most important point of reflection is the fact that it does not "move in a linear direction, from an object to its name. There is always a personality of the "reflector" behind the process". [17, p. 48; 6, p. 35] It means that the most important processes, connected with reflection take place in the logical link. Any immediate projecting of language phenomena onto the objective reality without taking into consideration the stage of thinking, should be regarded as such that allows considerable distortion of facts if not erroneous. The essence of mental processing of reality, that is of what is happening at the logical connecting link of reflection, may be characterised as "fusion" of objective and subjective. Keeping in mind that among the outer semiotic manifestations of this synthesis aimed at communicating information, the main place is occupied by utterances, it (the synthesis of objective and subjective) can be termed "predicativeness" (from lat. prae-dico-proclaim, narrate, indicate, refer to).

The authors' approach. Predicativeness may manifest itself in two forms - amorphous (vague, integral) or clearly structured. The first one is a historically primary form of reflection at the level of ideas (impressions). The other, well-structured form, - is a reflection at the level of proposition. In logic it is conventionally termed predication. Historically it is a secondary form with respect to the integral form of reflection. It evolved on the basis of predicativeness in the process of the cognitive development of thinking.

With the appearence of predication the initial form of predicativeness (we use the term "predicativeness" in two senses - broad (as in the first case) and more narrowly (as in the second sense) (in the future we are just going to call it "predicativeness" - to dissociate ourselves from "predication") did not pass out of use. Both forms function together harmoniously in the consciousness of people, complementing each other, and in many cases, passing from one form into the other.

Carrying the idea of the world order, the structure of predication is, at the same time, an embodiment of subjectivity. The clearest evidence of it is its ability to determine the relative significance of the substantial components of the process- relation, the most essential of which, acts in it as the subject of the proposition. This ability did not fail to attract attention of linguists as well, who while analysing the inner (semantic) structure of sentences, use such antonymous terms as "subject and object (of a thought)", "agent" - "patient", "bearer of the process" - "complement" (the closer) of the process, etc. Thanks to this ability, the structure of predication can act as a model the human activities process, in particular, as its imitation in proposition-relation. Compare: the subject of thought (substantial concept) - the predicate (specific nature of relation of the substantial concept in time + substantial concept - the closer of the action) // the subject of action (man) - kind of action - the object of action. Thus the structure of predication is not only the general formula of the world order, but also the imitation of the relations between the man and the world. Other subjective moments, being realized by the structure of predication, are also a projection of substantial concept in time, quantitative evaluation of this concept, evaluation of the relation of the perceived to the objective reality, such personal characteristics of the specificity of the substantial concept, as the beginning, the continuation, the end of the process, the necessity, the possibility of the latter, etc. So, as we can see, the structure of predication is the concentration of the ontological and subjective information about the world around us, in other words, it is the bearer of meaning.

An important point in the process of reflection worth our attention, is also the ability of thinking to perform operations on the model of algebraic ones.

On the level of language (speech) predicativeness is translated into utterances of two kinds: utterances - not sentences or just utterances (the term "utterance" like "predicativeness" is also used here in both broad and narrow senses) and utterances - sentences. The first type corresponds to the integral (holistic) reflection (on the level of imaginations), while the other one- to the structured form of reflection (on the level of judgments) is the voice of thoughts - elementary or extended.

The process of reflection on the level of language and thought allows us to clarify the grammatical essence of the more difficult examples: «Cвimaє», «Морозить», etc. The structured form 
of the verb - is the main variant of these utterances - it allows us to assume their correlation with the other form of reflection - the judgement. In contrast with ordinary cases, the peculiarity of the latter is that, out of the two constituents of its general (abstract) "formula" the concept of substantiality and the concept of its being in time and space -only the second constituent - the predicate - is brought to fruition in human conscience, due to which fact it can be easily embodied in the corresponding lexical form. As for the first constituent - the subject of judgement - it remains (continues to be realized) in abstract terms - as substantiality in general. That is one of the reasons of the fact that on the speech level it is just omitted, moreover, that the form of the verb-predicate - the third person singular - clearly points to the correlation of such utterances with a two-member judgement. No less important factor, which leads to the omission of the subject is the specific character of Slavic languages, particularly the free word- order, due to which the verbpredicate can "open" (or "close") a sentence.

To our mind these utterances should be qualified as monosyllabic sentences with an implicated subject of generalized substantial semantics or, traditionally, - as monosyllabic personal sentences. The verbal component in these sentences is the predicate. As to the utterances like: «Зима», «Ніч», «Мороз», etc., they correlate with the first type of reflection the holistic ("folded"). No wonder 0.O. Potebnya called them as the remainder of primitive, not yet structured forms of thinking in the distant past of the mankind [2]. The "folded" character of these utterances is manifested, in particular, in attempts to convert any of them into the status of a two-member one, that is to "to extend" it predicatively we will receive several variants: Зима > Прийла зима > Ось вже й зима > Надворі зима, etc. Taking all this into consideration, we will qualify this type of structures as utterances-not-sentences with integral structure of predication, or just predicatively-integral utterances.

The most interesting among the cases we are now speaking about are, undoubtedly, cases like: «Старику - под семьдесят», «Борму - иіла миска», etc. Their existence in language is caused by the transfer of one form into the other. The above mentioned utterances are, in our view, cases of utterances-not-sentences, which appeared on the basis of the second, evolved form of reflection reflection on the level of judgements. Utterances like «Борму - иіла миска» were formed on the basis of the structure of modification (<иіла миска> бориу) as the result of the reinvention of relations between the main member of this structure and its modifier in the direction to predicativeness. The utterance «Старику - под семьдесят» originates in the structure of complementation, in particular, in the object and the modifier of the verb in the sentence: $« Y$ даю этому старику под семьдесят». Similarly we can explain the utterance «Човен прибило вітром до берега». It is a predicatively reinvented derivative of the structure of complementation as a whole «прибивати чимось щось (до чогось)». These cases should be, in our opinion, qualified as utterances-not-sentences (predicative utterances), as, unlike the latter, they do not contain a formed structure of predication. As for semantics, these utterances do not express a thought, but only a hint of it, its vague contours. Many other cases can be explained in the same way.

Sometimes (it can be easily observed in Slavic languages) even the structure of predication itself is subjected to speech re-predicating. Evidence of that is, in particular, the fact that in the sentences like «Сестру отличает скромность», «Ее бьет дрожь» [18, p. 140-141], «С тетушкой обморок» [18, p. 135-136] there may appear certain relations similar to predicative among the components «Сестру», «Ее», «С тетушкой»: > Сестра - скромна; $>$ Она дрожит; > Тетушка в обмороке and other parts of these sentences. As we see it, it can be explained by the fact that, under certain conditions predicativeness overlaps the formed structure of predication - the bearer of the thought, and lends the thought a bit new accentuation, thus widening the capacity of language. As a result, on the level of language, we have a sentence, and on the level of speech - an utterance whose purpose (function) is to complete the idea, to lend certain connotation to its meaning.

The above analysed cases serve a good example of how thinking uses verbal "ore" for several times to adapt it to its own needs. Besides, they serve as evidence of dialectical unity between two main forms of reflection - predicativeness and predication, which may manifest itself in the diffusion of the two forms, transfer of one form into the other.

Conclusions. All abovementioned cases, as well as many others, have the same origin - all of them are nothing more but the language "imprint", the "result" of the "efforts" of thinking in its everlasting aspiration tendency to overcome the irresistible obstacle which exists between the means of the language and the infinity and diversity of the objective world around us.

\section{References:}

1. Галкина-Федорук Е.М. Суждение и предложение. Москва : Изд-во МГУ, 1956. $66 \mathrm{c}$.

2. Галкина-Федорук Е.М. Безличные предложения в современном русском языке / Вопросы синтаксиса современного русского языка. Москва: Учпедгиз. Мин. Просвещения РСФСР, 1950. C. $302-320$.

3. Попов П.С. Суждение и предложение / вопросы синтаксиса современного русского языка. Москва : Учпедгиз Мин. Просвещения РСФСР, 1950. С. 5-36.

4. Шахматов А.А. Синтаксис русского языка. Ленинград : Госуд. Учебно-педагогическое издание Наркомпроса РСФСР, 1941.620 c.

5. Кокорина С.Н. О семантическом субъекте и особенностях его выражения в русском языке. Москва : МГУ, 1979. 77 с.

6. Гвоздев А.Н. Современный русский язык. Ч.ІІ. Синтаксис. Москва : Учпедгиз, 1958. $301 \mathrm{c.}$

7. Вихованець I.Р. Граматика української мови: Синтаксис. К.: Либідь, 1993. 367 с.

8. Виноградов В.В. Русский язык (Грамматическое учение). Москва-Ленинград : Учпедгиз, 1947. 784 с.

9. Шведова Н.Ю. Очерки по синтаксису русской разговорной речи. Москва : АН СССР, 1960. 377 c.

10. Будде Е.О. Основы синтаксиса русского языка, Казань : Издание книжного магазина М.А. Голубева, 1913. 117 с.

11. Шульжук К.Ф. Синтаксис української мови. Київ : ВЦ Академія, $2010.408 \mathrm{c}$.

12. Дудик П.С., Прокопчук Л.В. Синтаксис української мови. Київ : ВЦ Академія, 2010. $384 \mathrm{c}$.

13. Ахманова О.С. Словарь лингвистических терминов. Москва : Советская энциклопедия, $1966.66 \mathrm{c}$.

14. Ганич Д.І., Олійник І.С. Словник лінгвістичних термінів. Київ : Вища школа, $1985.360 \mathrm{c}$.

15. Золотова Г.А. О принципах классификации простого предложения / Актуальные проблемы русского синтаксиса. Москва : МГУ, 1984. C. 14-18.

16. Золотова Г.А. Коммуникативные аспекты русского синтаксиса. Москва : Наука, АН СССР, Институт русского языка, 1982. 367 с.

17. Аветян Э.Г. Природа лингвистического знака. Ереван : МИТК, $1968,221 \mathrm{c}$. 
Жаборюк О. А., Жаборюк І. А. Проблема безособових речень у сучасних слов'янських мовах

Анотація. Проблема взаємовідношень між мовними та мовленнєвими структурами, зокрема й між їх основними одиницями - логічною та граматичною структурою предикації, належить до однієї з найсуттєвіших у лінгвістиці. Вона виникає через низку лінгвістичних явищ, які визначаються своєю неможливістю спроектовуватися на логічне судження. Це вирізняє їх серед висловів у індоєвропейських мовах.

У слов'янських мовах ці явища охоплюють три типи випадків: так звані «односкладні безособові речення», «односкладні номінативні речення» та такі досить характерні для цих мов висловлювання, як «Борщу - ціла миска», «Воды - по колено», "Mrówek naleciało" тощо.

Спостерігається багато суперечностей у трактуванні характеру їх співвіднесення з формами мислення.

На наш погляд, це можна пояснити тим, що за певних умов на сформовану структуру предикації - носія думки - накладається ще й предикативність, яка надає дум- ці дещо нового обрамлення, розширюючи можливості мови. Як наслідок, на рівні мови ми маємо речення, а на рівні мовлення - висловлювання, функція якого полягає в доповненні думки, наданні їй певного конотаційного значення.

Випадки, розглянуті у статті, є яскравим прикладом того, як саме мислення адаптує мовну «руду» до своїх потреб. Крім того, це є свідченням діалектичної єдності між двома формами віддзеркалення - предикацією та предикативністю, що виявляється у взаємопроникненні цих форм, перетіканні однієї в іншу.

Проаналізовані випадки мають однакову першопричину, адже всі вони є мовним «відбитком», «результатом» тих «зусиль», яких докладає мислення у прагненні подолати вічну, неподоланну суперечність, яка існує між засобами мови та безмежністю й розмаїтістю об'єктивного світу.

Ключові слова: безособове речення, односкладове речення, називне речення, висловлювання-не-речення, односкладові номінативні речення, присудок, предикація, предикативність. 